\title{
Zoogloea oryzae sp. nov., a nitrogen-fixing bacterium isolated from rice paddy soil, and reclassification of the strain ATCC 19623 as Crabtreella saccharophila gen. nov., sp. nov.
}

\author{
Correspondence \\ Cheng-Hui Xie \\ aa37116@mail.ecc.u-tokyo.ac.jp
}

\author{
Cheng-Hui Xie and Akira Yokota
}

Institute of Molecular and Cellular Biosciences, The University of Tokyo, 1-1-1 Yayoi, Bunkyo-Ku, Tokyo 113-0032, Japan

\begin{abstract}
Two strains of free-living diazotrophs isolated from soil from a rice paddy field were characterized by using a polyphasic approach. The novel strains, $A-7^{\top}$ and $A-4$, were found to be very closely related, with 99.9\% 16S rRNA gene sequence similarity and a DNA-DNA hybridization value of $89.5 \%$, suggesting that they represent a single species. $16 \mathrm{~S}$ rRNA gene sequence analyses indicated that the two strains fell within the Zoogloea lineage, with less than $96 \cdot 7 \%$ sequence similarity to other Zoogloea species. Chemotaxonomic characteristics of the novel strains, including DNA G + C content (65.1 mol\%), the major quinone system (Q-8), predominant fatty acids

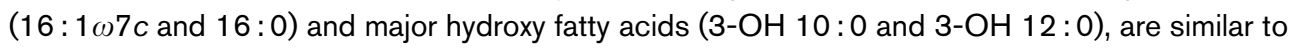
those of the genus Zoogloea. The novel strains showed positive results for floc formation which is accepted as confirmatory for species of the genus Zoogloea. However, the novel strains can be distinguished from the other species of Zoogloea by physiological characteristics. The name Zoogloea oryzae sp. nov. is therefore proposed for the novel strains with strain $A-7^{\top}(=I A M$ $15218^{\top}=$ CCTCC AB $2052005^{\top}$ ) as the type strain. Phylogenetic and chemotaxonomic analyses indicate that strain ATCC 19623, designated as a reference strain of Zoogloea ramigera, does not belong to the genus Zoogloea but to a new genus of Alphaproteobacteria. The name Crabtreella saccharophila gen. nov., sp. nov. is proposed for strain ATCC $19623^{\top}\left(=\right.$ IAM $\left.12669^{\top}\right)$.
\end{abstract}

Bacteria of the genus Zoogloea Itzigsohn 1868 are known to form characteristic cell aggregates embedded in gelatinous matrices, often called zoogloeal matrices (Dugan et al., 1992). Historically, the criteria for taxonomic classification in this genus were based on phenotypic characteristics and this has resulted in confusion in identifying members of this genus. Based on their quinone system and fatty acid analyses, strains ATCC 25935 (=IAM 12670) and ATCC 19623 ( = IAM 12669) of Zoogloea ramigera have been found to differ from the type strain of the species, strain ATCC $19544^{\mathrm{T}}$ ( = IAM $15300^{\mathrm{T}}$ ) (Hiraishi et al., 1992). This led to strain ATCC 25935 being transferred to Duganella zoogloeoides (Hiraishi et al., 1997), but the taxonomic position

Published online ahead of print on 28 October 2005 as DOI 10.1099/ ijs.0.63755-0.

Abbreviation: $\mathrm{PHB}$, poly- $\beta$-hydroxybutyrate.

The GenBank/EMBL/DDBJ accession numbers for the 16S rRNA and nifH gene sequences of strains $A-7^{\top}$ and A-4 are AB201043AB201044 and AB201045-AB201046, respectively.

A phylogenetic tree based on nifH gene sequences and a table detailing the fatty acid content of the three Zoogloea species are available as supplementary material in IJSEM Online. of strain ATCC 19623 (=IAM 12669) is still uncertain. To date, the genus Zoogloea comprises two species: the type species Z. ramigera (Crabtree \& McCoy, 1967) and Zoogloea resiniphila (Mohn et al., 1999). In this study, the taxonomic position of strain ATCC 19623 was further investigated by phylogenetic analyses together with earlier chemotaxonomic studies. We found that strain ATCC 19623 was phylogenetically related to the Alphaproteobacteria and distant from the genus Zoogloea. Phenotypic and chemotaxonomic analyses consistently support the fact that strain ATCC 19623 belongs to a new genus and species of the Alphaproteobacteria, for which the name Crabtreella saccharophila gen. nov., sp. nov. is proposed.

Strains A- $7^{\mathrm{T}}$ and A-4 were isolated from paddy soil associated with the roots of Oryza sativa in 1982 (Oyaizu-Masuchi \& Komagata, 1988). Since molecular studies had not been performed, the taxonomic position of the strains was uncertain. In this study, the phylogenetic relationship of the strains was deduced from the 16S rRNA gene sequence and it was found that the novel strains were closely related to $Z$. ramigera ATCC $19544^{\mathrm{T}}$, and the recently proposed species Z. resiniphila ATCC $700687^{\mathrm{T}}$ with $100 \%$ bootstrap support. The acetylene-reduction assay and sequencing of a partial 
fragment of the nifH gene (encoding the iron protein of nitrogenase) confirmed that the novel strains are nitrogenfixing bacteria, which distinguishes them from the two recognized species of the genus Zoogloea. The level of DNADNA relatedness between strains A-7 $7^{\mathrm{T}}$ and A- 4 was $89 \cdot 5 \%$. This strongly supports the assignment of the two strains as representatives of a single novel species.

The novel bacterial strains were grown in a nitrogen-free medium containing $\left(\mathrm{l}^{-1}\right), 10 \cdot 0$ g glucose, $0 \cdot 1 \mathrm{~g} \mathrm{CaCl}_{2} \cdot 2 \mathrm{H}_{2} \mathrm{O}$, $0 \cdot 1 \mathrm{~g} \mathrm{MgSO}_{4} .7 \mathrm{H}_{2} \mathrm{O}, 0.9 \mathrm{~g} \mathrm{~K}_{2} \mathrm{HPO}_{4}, 0 \cdot 1 \mathrm{~g} \mathrm{KH}_{2} \mathrm{PO}_{4}, 5 \mathrm{~g}$ $\mathrm{CaCO}_{3}, 10 \mathrm{mg} \mathrm{FeSO}_{4} \cdot 7 \mathrm{H}_{2} \mathrm{O}, 5 \cdot 0 \mathrm{mg} \mathrm{Na} \mathrm{MoO}_{4} \cdot 2 \mathrm{H}_{2} \mathrm{O}$ at $\mathrm{pH} 7 \cdot 3$ or supplemented with $0.5 \mathrm{~g}$ yeast extract $1^{-1}$ at $25^{\circ} \mathrm{C}$. Strains were also grown on a zoogloea medium, containing $\left(1^{-1}\right) 5.0 \mathrm{~g}$ casitone, $5.0 \mathrm{~g}$ glycerol, $0.5 \mathrm{~g}$ sodium lactate and $1.0 \mathrm{~g}$ yeast extract, or nutrient broth. Strains $Z$. ramigera IAM $15300^{\mathrm{T}}$, Z. resiniphila CIP $106709^{\mathrm{T}}$ and $Z$. ramigera IAM 12669 were also included in this study for fatty acid and physiological investigations. The formation of flocs was determined by test tube growth on LYS medium $\left[2.2 \mathrm{~g}\right.$ sodium lactate, $1.0 \mathrm{~g}\left(\mathrm{NH}_{4}\right)_{2} \mathrm{SO}_{4}, 0.6 \mathrm{~g} \mathrm{~K}_{2} \mathrm{HPO}_{4}$, $0.4 \mathrm{~g} \mathrm{KH}_{2} \mathrm{PO}_{4}, 0.5 \mathrm{~g}$ yeast extract, $0.05 \mathrm{~g}$ vitamin $\mathrm{B}_{12}$ and mineral base RM2 (IAM, 2004)] and was confirmed by examination with the naked eye and a phase-contrast microscope after 3 days incubation. DNA base composition, quinone system, acetylene-reduction assay and the presence of poly- $\beta$-hydroxybutyrate (PHB) granules were determined by the methods of Oyaizu-Masuchi \& Komagata (1988). Physiological characteristics were determined according to Cowan (1974) and then confirmed by the API 20NE and 50CHB microtest galleries (bioMérieux). Salinity tolerance was determined by inoculation in nutrient broth supplemented with $0-4 \cdot 0 \%(\mathrm{w} / \mathrm{v}) \mathrm{NaCl}$. Cellular fatty acid methyl esters were prepared, separated and identified using the Microbial Identification System as described by Xie \& Yokota (2003).
DNA-DNA hybridization was performed by the photobiotinlabelling method of Ezaki et al. (1989) using a multi-well plate reader (CytoFluoR; PerSeptive Biosystems). The hybridization temperature was $51^{\circ} \mathrm{C}$ and reciprocal experiments were performed as follows: the DNA of strain $A-7^{T}$ was hybridized to itself, to strain A-4 and to the negative control. PCR-mediated amplification of the 16S rRNA gene and sequencing of the PCR products were carried out as described previously (Xie \& Yokota, 2003). A 420-base fragment of the nifH gene sequence was amplified from the extracted DNA using the forward primer IGK, 5'-TACGGYAARGGBGGYATCGG-3' and the reverse primer AQE, 5'-GACGATGATYTCCTG-3' (Xie \& Yokota, 2004). DNA sequences were compared with those obtained from GenBank and aligned using the CLUSTAL $\mathrm{W}$ software package (Thompson et al., 1994) and evolutionary distances and $K_{\text {nuc }}$ values (Kimura, 1980) were generated. Alignment gaps and ambiguous bases were excluded from the calculation. A phylogenetic tree based on a comparison of 1249 bases was constructed using the neighbour-joining method (Saitou \& Nei, 1987). The topology of the phylogenetic tree was evaluated by the bootstrap resampling method of Felsenstein (1985) with 1000 replicates and similarity values were calculated using PAUP 4.0b1 (Swofford, 1998). Using the same method, 316 bases of nifH sequence were also aligned and a phylogenetic tree was constructed.

Strain A-7 ${ }^{\mathrm{T}}$ showed $99 \cdot 9 \% 16 \mathrm{~S}$ rRNA gene sequence similarity and $89.5 \%$ DNA-DNA relatedness to strain A-4, suggesting that they are members of a single species. Phylogenetic analysis of the $16 \mathrm{~S}$ rRNA gene sequence revealed that the novel strains fell within the Zoogloea lineage with $100 \%$ bootstrap support (Fig. 1). Sequence similarity also indicated that their closest relatives were $Z$. ramigera $(96 \cdot 7 \%)$ and $Z$. resiniphila $(95 \cdot 8 \%)$. The novel strains showed lower sequence similarities $(<95.0 \%)$ to all other recognized

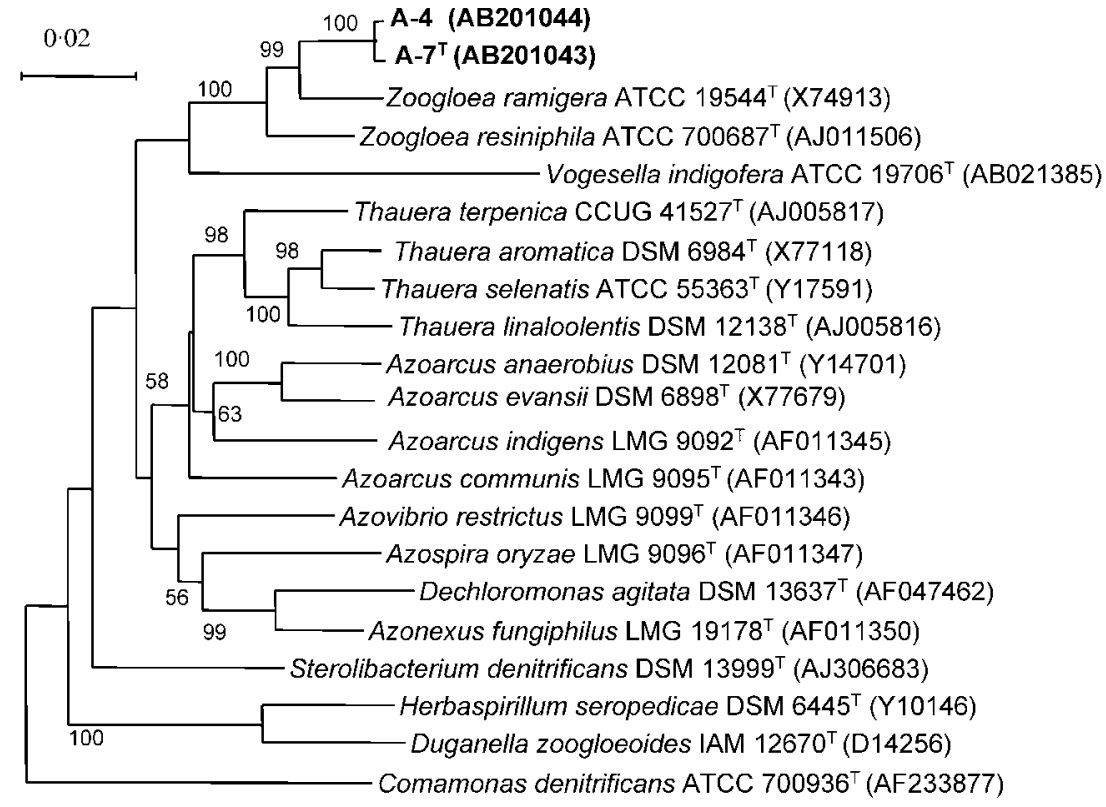

Fig. 1. Neighbour-joining phylogenetic tree based on 16S rRNA gene sequences showing the position of strains $A-7^{\top}$ and $A-4$ within the genus Zoogloea. Numbers at the nodes indicate the percentages of occurrence in 1000 bootstrapped trees; only values greater than $50 \%$ are shown. Bar, 2 substitutions per 100 nucleotides. 
species of the Betaproteobacteria. A nifH gene fragment was detected in the novel isolates and it was confirmed that they are capable of fixing nitrogen. Phylogenetic analysis based on the nifH gene sequence revealed that the novel isolates are closely related to the diazotrophic members of the family 'Rhodocyclaceae' such as Dechloromonas sp. SIUL (GenBank accession number AJ563286), Azoarcus indigens $\mathrm{VB}^{\mathrm{T}}$ (U97118) and Azoarcus communis S2 (U97117) (see Supplementary Fig. S1 in IJSEM Online). This cluster of bacteria showed phylogenetic discrepancies when compared with the $16 \mathrm{~S}$ rRNA gene sequences and this could be due to horizontal gene transfer (Hurek et al., 1997). Generally, at the family level, the two gene chronometers consistently indicate that the novel bacteria fall within the family 'Rhodocyclaceae' lineage. The novel strains are the first nitrogen-fixing bacteria to be assigned to the genus Zoogloea. Strain A-7 ${ }^{\mathrm{T}}$ showed less than $96 \cdot 7 \% 16 \mathrm{~S}$ rRNA gene sequence similarity to $Z$. ramigera and $Z$. resiniphila, a level sufficient to allow the proposal of a novel species (Stackebrandt \& Goebel, 1994). Moreover, the novel strains can be easily distinguished from $Z$. ramigera and $Z$. resiniphila by their phenotypic characteristics (Table 1).

Fragmented portions of flocs and pellicles could be observed with the naked eye in test tubes when strain A- $7^{\mathrm{T}}$ was incubated in LYS medium for 3 days. Zoogleae formations were identified by using a phase-contrast microscope. The respiratory quinone type also supports the affiliation of the strains to the Betaproteobacteria, where the majority of species (including $Z$. ramigera) have Q-8 as the major quinone (Yokota et al., 1992; Wen et al., 1999). The fatty acid profile of the novel strains is similar to those of the two recognized species of the genus Zoogloea, which possess large amounts of $16: 1 \omega 7 c$ and $16: 0$ and have $3-\mathrm{OH} 10: 0$

Table 1. Characteristics that distinguish $Z$. ramigera IAM $15300^{\top}$, strain $A-7^{\top}$ and $Z$. resiniphila CIP $106709^{\top}$

\begin{tabular}{|lccc|}
\hline Characteristic & $\begin{array}{c}\text { IAM } \\
\mathbf{1 5 3 0 0}^{\mathbf{T}}\end{array}$ & $\mathbf{A - 7}^{\mathrm{T}}$ & $\begin{array}{c}\text { CIP } \\
\mathbf{1 0 6 7 0 9}^{\mathrm{T}}\end{array}$ \\
\hline Cell diameter & $1 \cdot 0-1 \cdot 2$ & $0 \cdot 5-0 \cdot 7$ & $1 \cdot 0$ \\
Growth at $45^{\circ} \mathrm{C}$ & - & - & $+^{*}$ \\
Catalase & + & + & - \\
Hydrolysis of gelatin and casein & + & - & $+^{*}$ \\
Denitrification to $\mathrm{N}_{2}$ & + & + & - \\
Voges-Proskauer test & - & - & + \\
Gelatinase & - & - & $\mathrm{W}$ \\
Urease & + & + & - \\
Utilizes as sole carbon source: & & & \\
$\quad$ Acetate & + & - & + \\
Citrate & + & - & - \\
Glucose & - & - & + \\
Melibiose & + & - & $\mathrm{W}$ \\
Pyruvate & + & - & + \\
Rhamnose & - & - & + \\
\hline
\end{tabular}

${ }^{\star}$ Data from Mohn et al. (1999). and 3-OH $12: 0$ as the major hydroxy fatty acids. The fatty acids of $Z$. resiniphila are a little different from the others (see Supplementary Table S1 in IJSEM Online). Colonies of the novel strains are colourless and cells are Gram-negative rods that are motile by monotrichous flagella. The novel strains show accumulation of PHB, are catalase-, oxidaseand urease-positive, show denitrification to $\mathrm{N}_{2}$ and do not form acid from carbohydrates. These phenotypic characteristics are in excellent agreement with the general description of the genus Zoogloea (Unz, 1984). Strains A- $7^{\mathrm{T}}$ and A-4 can grow well in nitrogen-free medium. Their nitrogen fixation capability was identified by the acetylene-reduction assay and nifH gene detection, but the other species of Zoogloea do not show this ability. Moreover, the novel isolates can be differentiated from the two recognized species of Zoogloea by the presence of catalase activity and the hydrolysis of gelatin, casein and other substances (Table 1). Based on phylogenetic and phenotypic analyses, the two novel strains are therefore proposed as representing a novel bacterium of the genus Zoogloea.

Strain IAM 12669 was derived from strain ATCC 19623 and the 16S rRNA gene sequences of these strains have been deposited in the GenBank/EMBL/DDBJ databases with accession numbers X74915 and D14255. We found six nucleotide mismatches between the two strains, including ambiguous bases. We determined the $16 \mathrm{~S}$ rRNA gene sequence of strain IAM 12669 (GenBank accession no. $\mathrm{AB} 238789)$ and found that it had $100 \%$ similarity with X74915, apart from two ambiguous bases (NN) that appear in the first section of X74915. A phylogenetic tree based on a 1302 bp alignment was constructed using the neighbourjoining method (Fig. 2). Strain ATCC 19623 (=IAM 12669) was distantly related to the typical strains of $Z$. ramigera (Betaproteobacteria). Furthermore, the quinone system (Q-10) supports the affiliation of strain ATCC 19623 to the Alphaproteobacteria (Lechner et al., 1995; Yokota et al., 1992). A $16 S$ rRNA gene sequence search revealed that the closest relatives of strain ATCC 19623 were two uncultured bacteria, clone HP1B02 and clone 015B-H01 (McMahon et al., 2002), with $98.5 \%$ sequence similarity, but strain ATCC 19623 showed no more than $95.9 \%$ sequence similarity to the other taxa within the Alphaproteobacteria. Strain ATCC 19623 and the uncultured bacteria were isolated from activated sludge systems and uranium-contaminated groundwater. They formed a monophyletic cluster and were a sister phyletic group to Mycoplana dimorpha IAM $13154^{\mathrm{T}}$ with poor bootstrap support. Phylogenetic analyses using the maximum-likelihood method also strongly supported the suggestion that strain IAM 12669 and the uncultured bacteria form an independent cluster not related to other taxa (data not shown). Comparisons of the taxonomic characteristics support this conclusion. Strain IAM 12669 has a large amount of fatty acid $18: 1 \omega 7 c(78 \cdot 1 \%)$ with smaller amounts of $16: 0(6 \cdot 2 \%), 19: 010$-methyl $(2 \cdot 7 \%), 16: 1 \omega 7 c$ $(2 \cdot 0 \%), 13: 1$ at $12-13(1 \cdot 8 \%)$ and $18: 0(1 \cdot 6 \%)$. The major hydroxy fatty acids of strain IAM 12669 are 3-OH 16:0 $(5 \cdot 4 \%), 3-\mathrm{OH} 14: 0(0 \cdot 7 \%)$ and $3-\mathrm{OH} 18: 0(0 \cdot 6 \%)$, which 


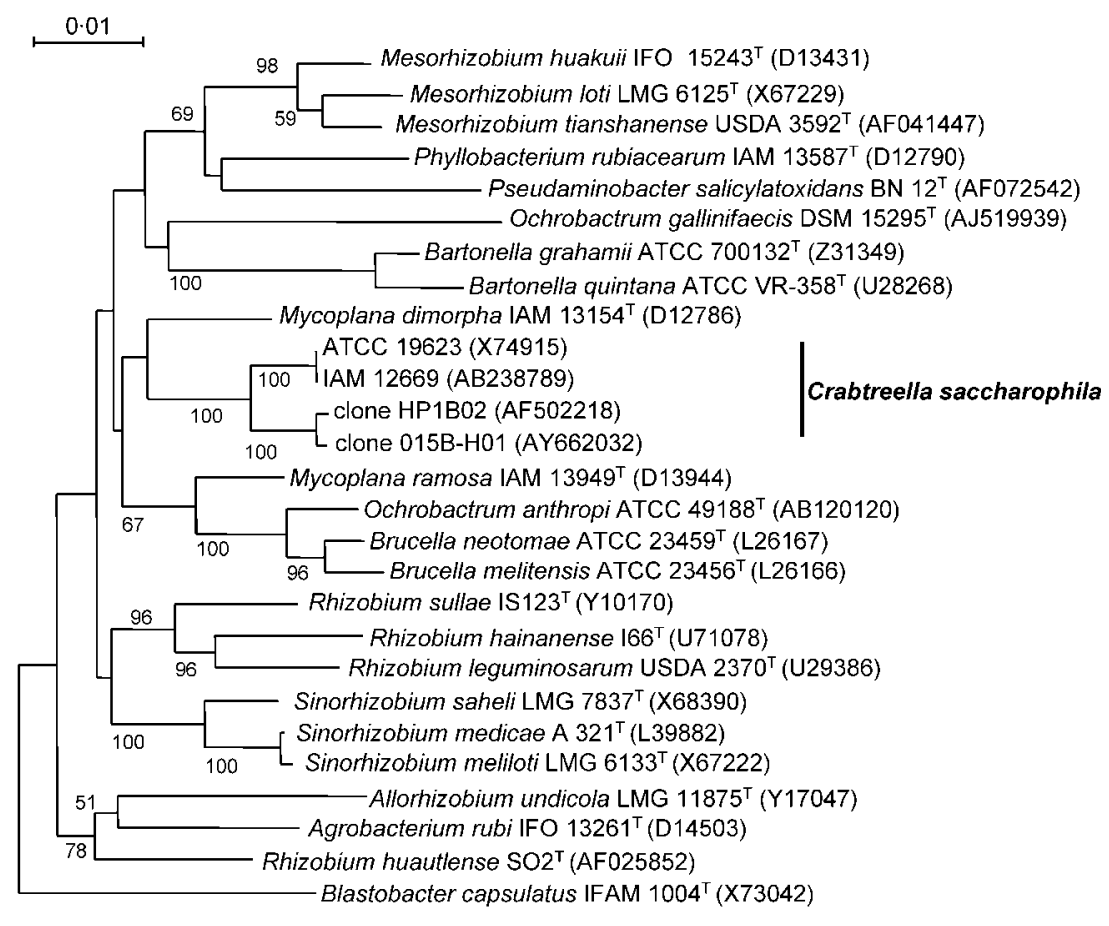

Fig. 2. Neighbour-joining phylogenetic tree based on 16S rRNA gene sequences showing the position of strain ATCC 19623 distinct from other taxa within the Alphaproteobacteria. Numbers at the nodes indicate the percentages of occurrence in 1000 bootstrapped trees; only values greater than $50 \%$ are shown. Bar, 1 substitution per 100 nucleotides. clearly distinguishes the strain from its phylogenetic neighbours Mycoplana (Urakami et al., 1990), Rhizobium, Mesorhizobium and Ochrobactrum (Tighe et al., 2000). Moreover, phenotypic characteristics also provide evidence that strain IAM 12669 cannot be characterized as a member of any known genus within the family Rhizobiales of the Alphaproteobacteria (Table 2). These results are in agreement with the phenotype found by Unz (1971), who rejected this strain as a representative of $Z$. ramigera. Therefore, we propose that strain IAM 12669 represents a new genus and novel species, Crabtreella saccharophila gen. nov., sp. nov.

\section{Description of Zoogloea oryzae sp. nov.}

Zoogloea oryzae (o.ry'zae. L. gen. n. oryzae of rice, from the rice paddy fields from which the strains were isolated).

Cells are straight or curved, $0 \cdot 5-0 \cdot 7 \times 1 \cdot 5-2.0 \mu \mathrm{m}$ and motile with a polar flagellum. Single or pairs of cells are observed. Growth occurs from 10 to $37^{\circ} \mathrm{C}$, but not at 4 or $40{ }^{\circ} \mathrm{C}$. Growth is inhibited by $0.5 \% \mathrm{NaCl}$. Flocs are formed at late growth stages and cells become embedded in gelatinous matrices to form zoogloeae, which are distinguished by a 'tree-like' morphology. Colonies are $<1 \mathrm{~mm}$ in diameter

Table 2. Differential characteristics of strain IAM 12669 and Mycoplana dimorpha ATCC $4279^{\top}$. Data for M. dimorpha ATCC $4279^{\top}$ are from Urakami et al. (1990)

\begin{tabular}{|c|c|c|}
\hline Characteristic & IAM 12669 & ATCC $4279^{\mathrm{T}}$ \\
\hline Cell diameter $(\mu \mathrm{m})$ & $0 \cdot 5-1 \cdot 0$ & $0 \cdot 8$ \\
\hline Flagella arrangement & Polytrichous & Peritrichous \\
\hline Colony colour & Straw-coloured & White to light yellow \\
\hline Growth on $3 \% \mathrm{NaCl}$ & + & - \\
\hline \multicolumn{3}{|l|}{ Litmus milk test:* } \\
\hline Alkalinity produced & + & - \\
\hline Reduction occurs & + & - \\
\hline Urease & - & + \\
\hline \multicolumn{3}{|l|}{ Acid formed oxidatively from: } \\
\hline Maltose & + & - \\
\hline Mannose & - & + \\
\hline Sucrose & + & - \\
\hline Utilizes methanol as sole carbon source & + & - \\
\hline Major hydroxy acids (3-OH) & $16: 0 ; 14: 0 ; 18: 0$ & $14: 0$ \\
\hline
\end{tabular}

${ }^{\star}$ Data from Unz (1984). 
and colourless in nitrogen-free medium. PHB accumulates in cells. Viscid slime and water-soluble fluorescent pigments are not produced in King A and B medium or in mannitolyeast extract medium. Nitrogen-fixing. Catalase, oxidase and urease activities are present, but not DNase or tyrosinase activity. Nitrate reduction is positive, but indole production and gelatin, starch and Tween 80 hydrolysis are negative. Acid is not produced from glucose oxidatively or fermentatively. Most carbohydrates, such as glucose, arabinose, fructose, sucrose, galactose, maltose, xylose, mannitol, rhamnose, ribose, mannose, lactose, acetate and citrate, cannot be used as a sole carbon source. The quinone system is Q- 8 . The major fatty acids are $16: 1 \omega 7 c$ and $16: 0$. The major hydroxy fatty acids are 3-OH 10:0 and 3-OH 12:0. The DNA G+C content is $65 \cdot 1 \mathrm{~mol} \%$.

The type strain, $A-7^{\mathrm{T}} \quad\left(=\mathrm{IAM} \quad 15218^{\mathrm{T}}=\mathrm{CCTCC} \quad \mathrm{AB}\right.$ $2052005^{\mathrm{T}}$ ), was isolated from soil from a rice paddy field.

\section{Description of Crabtreella gen. nov.}

Crabtreella (Crab.tre' el.la. N.L. fem. n. Crabtreella named after Dr K. Crabtree, the American microbiologist who isolated the type strain of the type species).

The description is based on the data compiled by Unz (1971) and this study. Cells are Gram-negative, straight rods with rounded, blunt or tapered ends. The cells are $0 \cdot 6-0 \cdot 9 \mu \mathrm{m}$ wide and $1 \cdot 5-2 \cdot 0 \mu \mathrm{m}$ long with one to several flagella that are attached laterally. Growth occurs on $3 \% \mathrm{NaCl}$, but not $6 \% \mathrm{NaCl}$. PHB is accumulated. Zoogloea formation is absent. Catalase and oxidase activities are present, but urease activity and nitrate reduction are absent. The quinone system is Q-10. The major fatty acids is $18: 1$. The major hydroxy fatty acids are 3-OH 16:0, 3-OH 14:0 and 3-OH 18:0. The type species is Crabtreella saccharophila.

\section{Description of Crabtreella saccharophila sp. nov.}

Crabtreella saccharophila (sacc.ha.ro.phi'la. Gr. n. saccharon sugar; Gr. adj. philos loving; N.L. fem. adj. saccharophila sugar-loving).

Displays the following properties in addition to those given in the genus description. Cells grow in CY medium $(5.0 \mathrm{~g}$ casitone and $1.0 \mathrm{~g}$ yeast extract). Colonies are strawcoloured. The optimum $\mathrm{pH}$ for growth is $7 \cdot 0-7 \cdot 5$ with no growth at $\mathrm{pH} 4.5$ or $9 \cdot 6$. The optimum temperature is $28-30{ }^{\circ} \mathrm{C}$, with slow growth at $10^{\circ} \mathrm{C}$ and no growth at $45^{\circ} \mathrm{C}$. Tributyrin is hydrolysed. $\mathrm{H}_{2} \mathrm{~S}$ is produced in a peptonecysteine-sulfated medium. Arginine dihydrolase is present. Hydrolyses tyrosine agar and brown pigment appears. Utilizes acetate, pyruvate, malate, fumarate, oxalacetate, asparagine, aspartate, glutamate, citrulline, ornithine, arginine, histidine, tyrosine, ammonia, n-propanol, ethanol, $n$ butanol and ethanol, but not citrate, benzoate or $m$-toluate. Acid is formed oxidatively from arabinose, ethanol, rhamnose, ribose, xylose, fructose, glucose, glycerol, mannitol and sucrose, but no acid is formed from starch or inulin.
Indole is not produced. Nitrate is not reduced to nitrite and nitrogen gas. The DNA G $+\mathrm{C}$ content is $65 \cdot 3 \mathrm{~mol} \%$.

The type strain is IAM $12669^{\mathrm{T}}\left(=\right.$ ATCC $\left.19623^{\mathrm{T}}\right)$.

\section{Acknowledgements}

We are indebted to Dr Kazuo Komagata for providing the strains.

\section{References}

Cowan, S. T. (1974). Cowan and Steel's Manual for the Identification of Medical Bacteria, 2nd edn, pp. 137-180. Cambridge: Cambridge University Press.

Crabtree, K. \& McCoy, E. (1967). Zoogloea ramigera Itzigsohn, identification and description. Request for an opinion as to the status of the generic name Zoogloea. Int J Syst Bacteriol 17, 1-10.

Dugan, P. R., Stoner, D. L. \& Pickrum, H. M. (1992). The genus Zoogloea. In The Prokaryotes, 2nd edn, pp. 3952-3964. Edited by A. Balows, H. G. Trüper, M. Dworkin, W. Harder \& K.-H. Schleifer. New York: Springer.

Ezaki, T., Hashimoto, Y. \& Yabuuchi, E. (1989). Fluorometric deoxyribonucleic acid-deoxyribonucleic acid hybridization in microdilution wells as an alternative to membrane filter hybridization in which radioisotopes are used to determine genetic relatedness among bacterial strains. Int J Syst Bacteriol 39, 224-229.

Felsenstein, J. (1985). Confidence limits on phylogenies: an approach using the bootstrap. Evolution 39, 783-791.

Hiraishi, A., Shin, Y. K., Sugiyama, J. \& Komagata, K. (1992). Isoprenoid quinones and fatty acids of Zoogloea. Antonie van Leeuwenhoek 61, 231-236.

Hiraishi, A., Shin, Y. K. \& Sugiyama, J. (1997). Proposal to reclassify Zoogloea ramigera IAM 12670 (P. R. Dugan 115) as Duganella zoogloeoides gen. nov., sp. nov. Int J Syst Bacteriol 47, 1249-1252.

Hurek, T., Egener, T. \& Reinhold-Hurek, B. (1997). Divergence in nitrogenases of Azoarcus spp., Proteobacteria of the beta subclass. $J$ Bacteriol 179, 4172-4178.

IAM (2004). Catalogue of Strains. p. 308. Tokyo; Center for Cellular and Molecular Research, Institute of Molecular and Cellular Biosciences, University of Tokyo.

Kimura, M. (1980). A simple method for estimating evolutionary rates of base substitutions through comparative studies of nucleotide sequences. J Mol Evol 16, 111-120.

Lechner, U., Baumbach, R., Becker, D., Kitunen, V., Auling, G. \& Salkinoja-Salonen, M. (1995). Degradation of 4-chloro-2methylphenol by an activated sludge isolate and its taxonomic description. Biodegradation 6, 83-92.

McMahon, K. D., Dojka, M. A., Pace, N. R., Jenkins, D. \& Keasling, J. D. (2002). Polyphosphate kinase from activated sludge performing enhanced biological phosphorus removal. Appl Environ Microbiol 68, 4971-4978.

Mohn, W. W., Wilson, A. E., Bicho, P. \& Moore, E. R. B. (1999). Physiological and phylogenetic diversity of bacteria growing on resin acids. Syst Appl Microbiol 22, 68-78.

Oyaizu-Masuchi, Y. \& Komagata, K. (1988). Isolation of free-living nitrogen-fixing bacteria from the rhizosphere of rice. J Gen Appl Microbiol 34, 127-164.

Stackebrandt, E. \& Goebel, B. M. (1994). Taxonomic note: a place for DNA-DNA reassociation and 16S rRNA sequence analysis in the present species definition in bacteriology. Int J Syst Bacteriol 44, 846-849. 
Swofford, D. L. (1998). PAUP ${ }^{*}$ - Phylogenetic Analysis Using Parsimony ${ }^{*}$ and other methods, version 4 . Sunderland, MA: Sinauer Associates.

Thompson, J. D., Higgins, D. G. \& Gibson, T. J. (1994). CLUSTAL W: improving the sensitivity of progressive multiple sequence alignment through sequence weighting, position-specific gap penalties and weight matrix choice. Nucleic Acids Res 22, 4673-4680.

Tighe, S. W., de Lajudie, P., Dipietro, K., Lindstrom, K., Nick, G. \& Jarvis, B. D. (2000). Analysis of cellular fatty acids and phenotypic relationships of Agrobacterium, Bradyrhizobium, Mesorhizobium, Rhizobium and Sinorhizobium species using the Sherlock Microbial Identification System. Int J Syst Evol Microbiol 50, 787-801.

Unz, R. F. (1971). Neotype strain of Zoogloea ramigera Itzigsohn. Request for an opinion. Int J Syst Bacteriol 21, 91-99.

Unz, R. F. (1984). Genus IV. Zoogloea Itzigsohn 1868, 30 $0^{\mathrm{AL}}$. In Bergey's Manual of Systematic Bacteriology, vol. 1, pp. 214-219. Edited by N. R. Krieg \& J. G. Holt. Baltimore: Williams \& Wilkins.
Urakami, T., Oyanagi, H., Araki, H., Suzuki, K. \& Komagata, K. (1990). Recharacterization and emended description of the genus Mycoplana and description of two new species, Mycoplana ramosa and Mycoplana segnis. Int J Syst Bacteriol 40, 434-442.

Wen, A., Fegan, M., Hayward, C., Chakraborty, S. \& Sly, L. I. (1999). Phylogenetic relationships among members of the Comamonadaceae, and description of Delftia acidovorans (den Dooren de Jong 1926 and Tamaoka et al. 1987) gen. nov., comb. nov. Int J Syst Bacteriol 49, $567-576$

Xie, C. H. \& Yokota, A. (2003). Phylogenetic analyses of Lampropedia hyalina based on the 16S rRNA gene sequence. J Gen Appl Microbiol 49, 345-349.

Xie, C. H. \& Yokota, A. (2004). Phylogenetic analyses of the nitrogenfixing genus Derxia. J Gen Appl Microbiol 50, 129-135.

Yokota, A., Akagawa-Matsushia, M., Hiraishi, A., Katayama, Y., Urakami, T. \& Yamasato, K. (1992). Distribution of quinone systems in microorganisms: Gram-negative eubacteria. Bull Jpn Fed Cult Coll 8, $136-171$. 